\title{
Correction to: Herbivory by aboveground insects impacts plant root morphological traits
}

\author{
Johannes Heinze
}

Published online: 21 October 2021

(C) The Author(s) 2021

\section{Correction to: Plant Ecol (2020) 221:725-732 \\ https://doi.org/10.1007/s11258-020-01045-w}

The article "Herbivory by aboveground insects impacts plant root morphological traits", written by "Johannes Heinze", was originally published Online First without Open Access. After publication in volume 221 , issue 8 , page 725-732 the author decided to opt for Open Choice and to make the article an Open Access publication. Therefore, the copyright of the article has been changed to (C) The Author(s) 2021 and the article is forthwith distributed under a Creative Commons Attribution 4.0 International License, which permits use, sharing, adaptation, distribution and reproduction in any medium or format, as long as you give appropriate credit to the original author(s) and the source, provide a link to the Creative Commons licence, and indicate if changes were made.

The original article can be found online at https:// doi.org/10.1007/s11258-020-01045-w.

J. Heinze $(\bowtie)$

Biodiversity Research/Systematic Botany, Institute of Biochemistry and Biology, University of Potsdam, Maulbeerallee 1, 14469 Potsdam, Germany e-mail: jheinze@uni-potsdam.de

\section{J. Heinze}

Berlin-Brandenburg Institute of Advanced Biodiversity

Research (BBIB), Altensteinstr. 6, 14195 Berlin,

Germany
The images or other third party material in this article are included in the article's Creative Commons licence, unless indicated otherwise in a credit line to the material. If material is not included in the article's Creative Commons licence and your intended use is not permitted by statutory regulation or exceeds the permitted use, you will need to obtain permission directly from the copyright holder. To view a copy of this licence, visit https://creativecommons.org/ licenses/by/4.0.

The original article has been corrected.

Open Access This article is licensed under a Creative Commons Attribution 4.0 International License, which permits use, sharing, adaptation, distribution and reproduction in any medium or format, as long as you give appropriate credit to the original author(s) and the source, provide a link to the Creative Commons licence, and indicate if changes were made. The images or other third party material in this article are included in the article's Creative Commons licence, unless indicated otherwise in a credit line to the material. If material is not included in the article's Creative Commons licence and your intended use is not permitted by statutory regulation or exceeds the permitted use, you will need to obtain permission directly from the copyright holder. To view a copy of this licence, visit http://creativecommons.org/licenses/by/4.0/.

Publisher's Note Springer Nature remains neutral with regard to jurisdictional claims in published maps and institutional affiliations. 